\section{Risk Alma Eğilimi Ve Başarma İhtiyacının Girişimcilik Potansiyeline Etkisi: Üniversite Öğrencileri Üzerine Bir Araştırma}

\author{
Aydın ÖZDEMIR \\ Adryaman Üniversitesi, Besni Meslek Yüksekokulu, \\ aozdemir@adiyaman.edu.tr \\ Metin SAYGILI \\ Sakarya Üniversitesi Sosyal Bilimler Enstitüsü, İsletme EABD \\ metinsaygili@msn.com
}

Kadir YILDIRIM

Sakarya Üniversitesi, Sosyal Bilimler Enstitüsü, İsletme EABD

kadiry@sakarya.edu.tr
Risk Alma

Eğilimi Ve

Başarma

İhtiyacının

Girişimcilik

Potansiyeline

Etkisi:

Üniversite

Öğrencileri

Üzerine Bir

Araştırma

121

\title{
ÖZET
}

$\mathrm{Bu}$ araştırmada girişimci kişilik özelliklerinden risk alma eğilimi ve başarma ihtiyacının girişimcilik potansiyeli üzerindeki etkilerinin incelenmesi amaçlanmıştır. Bu amaca yönelik bir devlet üniversitesinin meslek yüksekokulunda 2015-2016 akademik yılında öğrenim gören 475 öğrenci üzerinde kolayda örnekleme yöntemi benimsenerek, yüz yüze ve online (mail yoluyla) anket uygulaması gerçekleştirilmiştir. Risk alma eğilimi, başarma ihtiyacı ve girişimcilik potansiyelini ölçmek amacıyla toplamda 24 ifaden oluşan 5'li Likert tipi ölçek kullanılarak elde edilen veriler, SPSS 23.0 ve AMOS 23.0 istatistiki analiz paket programlarında analize tabi tutulmuştur. Ölçeklerin her birine ait tek boyutlu yapıları ortaya koymak amacıyla Doğrulayıcı Faktör Analizi (DFA) ve araştırmanın hipotezlerini test etmek amacıyla ise Çok Değişkenli Regresyon Analizi gerçekleştirilmiştir. Araştırmanın bulguları, girişimci kişilik özelliklerinden başarma ihtiyacı $(\beta=0.42, p<0.01)$ ve risk alma eğiliminin $(\beta=0.41, p<0.01)$ girişimcilik potansiyeli üzerinde pozitif etkilerinin olduğu ortaya koymaktadır.

Anahtar Kelimler: Girişimcilik Potansiyeli, Risk Alma Eğilimi, Başarma İhtiyac1 
Risk Alma Eğilimi Ve

Başarma İhtiyacinın

Girişimcilik

Potansiyeline

Etkisi:

Üniversite

Öğrencileri Üzerine Bir Araştırma

122

\section{Effect Of Risk Takıng Tendency And Achievement \\ Need On Enterpreneurship Potential: A Research On \\ University Students}

\begin{abstract}
In this research it was aimed to examine the effects of risk taking tendency and achievement need as personality traits on enterpreneurship potential. For this purpose questionnaire technique was applied to 475 students which were educating in 2015-2016 academic year in a Vocational High School by using simple random sampling via face to face and online (by mail). Data was analyzed in SPSS 23.0 and AMOS 23.0 statistics analysis programmes which was gathered by using 5 point Likert scale consisting 24 items in order to measure risk taking tendency, achievement need and enterpreneurship potential. Confirmatory Factor Analysis (CFA) for exhibiting each scale's single dimensional construct and Multi Variable Regression Analysis for testing hypotheses were applied. Research findings indicate that achievement need $(\beta=0.42, \mathrm{p}<0.01)$ and risk taking tendency $(\beta=0.41, p<0.01)$ as personality traits have positive effects on enterpreneurship potential.
\end{abstract}

Keywords: Enterpreneurship Potential, Risk Taking Tendency, Achievement Need

\section{I.GİRIŞ}

Toplumsal yapının odağının sanayiden bilgiye yönelmesiyle birlikte büyük bir önem kazanan ve özellikle son 20 yıldır üzerinde yoğun olarak durulan girişimcilik, ekonomik ilerleme ve toplumsal refahı sağlayan temel katalizör güç olarak değerlendirilmektedir. Girişimcilik kavramına tüm alanlarda kalkınma ve gelişmenin temel yapı taşı olarak bakılmaktadır. Girişimci ve girişimcilik kavramları günümüzde hayat standartlarını yükseltmeye yönelik birçok alanda önemli bir unsur olarak karşımıza çıkmakta ve buna bağlı olarak risk alma eğilimi, başarma ihtiyacı ve girişimcilik potansiyeli gibi kavramlar sıkça duyulmaktadır.

Girişimciler, toplumların çağdaşlığa doğru yürüyüşünde önemli roller üstlendikleri gibi sadece ekonomik hayatın değil bununla birlikte toplumsal hayatın kalitesinin artmasına da katkıda bulunmaktadırlar. Girişimcilerin bu rolleri hayata geçirme süreci olarak karşımıza çıkan 
girişimcilik ise, emek, teknoloji, sermaye ve doğal kaynaklar gibi üretim faktörlerinin bir araya getirilip, mal ve hizmet üretme eylemini kapsar.

Bu bağlamda, bu çalışmada girişimci kişilik özellikleri içerisinde yer alan başarma ihtiyacı ve risk alma eğiliminin, girişimcilik potansiyeline etkileri ve bunların birbirileriyle ilişkileri incelenecek olup araştırmanın örneklemini Adıyaman Üniversitesi Besni Meslek Yüksekokulu'nda öğrenim gören öğrenciler oluşturmaktadır.

Üniversite öğrencilerinin geleceğin potansiyel girişimcileri olması nedeniyle girişimci kişilik özelliklerinden başarma ihtiyacı ve risk alma eğiliminin, girişimcilik potansiyeline etkilerinin ve bu kavramların birbirleriyle ilişkilerinin tespit edilmeye çalışıldığı bu araştırma girişimciliğin etkilendiği kişilik özelliklerini ortaya çıkarması bakımından önem arz etmektedir.

\section{KAVRAMSAL ÇERÇEVE}

\subsection{Girişimcilik ve Girişimci}

Girişimci ve girişimcilik kavramlarını anlamak ve açıklamak amacıyla yapılan birçok araştırma olmasına rağmen, her iki kavram için üzerinde uzlaşılmış ortak bir tanımdan söz etmek mümkün değildir (Koh, 1996: 13). Farklılığın ana nedeni; her iki kavramın çok boyutlu özellikler taşıması ve çok geniş bir çerçevede yer almasıdır (Ören ve Biçkes, 2011: 70).

Girişimciliğin bir süreç, girişimcinin ise bu sürecin sahibi olarak değerlendirildiğinde; girişimci ve girişimcilik kavramlarına ilişkin farklı perspektifleri ortaya çıkarmak amacıyla literatürde farklı tanımlamalar yapılmaktadır (Arıkan, 2004: 46). Girişimci ve girişimcilik kavramlarına ait yazında (Meredith ve Diğ., 1984, Şenocak, 1992, Hinterhuber and Popp, 1992, Titiz,1994, Bull ve Willard 1995, Çetin 1996, Farell 1997, Beatty 1998, Çetindamar 2002, Foss and Klein 2002, Girginer ve Uçkun, 2004, Eyuboğlu, 2004) çok sayıda tanımın yer aldığı görülmektedir. Literatürde yer alan girişimci kavramı ile ilgili tanımlar Tablo 1'de; girişimcilik kavramı ile ilgili tanımlar ise Tablo 2'te özetlenmektedir.
Risk Alma

Eğilimi Ve

Başarma

İhtiyacinın

Girişimcilik

Potansiyeline

Etkisi:

Üniversite

Öğrencileri

Üzerine Bir

Araştırma

123 
Risk Alma

Eğilimi Ve

Başarma

İhtiyacinın

Girişimcilik

Potansiyeline

Etkisi:

Üniversite

Öğrencileri

Üzerine Bir

Araştırma

124
Tablo 1.

Araştırmacılara Göre “Girişimci” Tanımları

\begin{tabular}{|c|c|}
\hline Yazar & Tanım \\
\hline $\begin{array}{l}\text { Binks ve } \\
\text { Vale (1990) }\end{array}$ & $\begin{array}{l}\text { Kıt kaynakların eşgüdümlenmesiyle ilgili sağlıklı ve akılcı } \\
\text { kararlar almada uzmanlaşan kişi şeklinde } \\
\text { tanımlanmaktadır. }\end{array}$ \\
\hline $\begin{array}{l}\text { Titiz } \\
(1999)\end{array}$ & $\begin{array}{l}\text { Sürekli olarak var olan durumun ötesine geçebilmek } \\
\text { amaciyla, üretkenlik yeteneğini kullanan kişidir. }\end{array}$ \\
\hline $\begin{array}{l}\text { Emsen } \\
(2001)\end{array}$ & $\begin{array}{l}\text { Çeşitli üretim faktörlerini birleştirerek risk üstlenen ve } \\
\text { kendi işini kurarak üretim sürecinde yer alan ve } \\
\text { neticesinde da kar elde etmeyi amaçlayan kişi olarak } \\
\text { tanımlanmaktadır. }\end{array}$ \\
\hline $\begin{array}{l}\text { Ireland, Hitt } \\
\text { ve Sirmon } \\
(2003)\end{array}$ & $\begin{array}{l}\text { Daha önce hiç kimse tarafından farkına varılmamış } \\
\text { fırsatları tespit edip, kullanabilen kişidir. }\end{array}$ \\
\hline $\begin{array}{l}\text { Top } \\
(2006)\end{array}$ & $\begin{array}{l}\text { Bireyi temel alan ve bireye ait özel yetenek, beceri ve } \\
\text { zihinsel kapasitelere vurgu yapan bir kavram olup } \\
\text { stratejik rekabet açısından geleceği şekillendirebilecek } \\
\text { kaynak ve yetenekleri inşa etmek için harekete geçen, } \\
\text { düşünce ve eylemleriyle değer yaratma işidir. }\end{array}$ \\
\hline $\begin{array}{l}\text { Yalçıntaş } \\
(2007)\end{array}$ & $\begin{array}{l}\text { Ekonomik değere ulaşmak amacıyla yaratıcılık, yenilik ve } \\
\text { fırsatların peşinde koşarak risk alan kişidir. }\end{array}$ \\
\hline $\begin{array}{l}\text { Karahan ve } \\
\text { Ulusoy } \\
(2010)\end{array}$ & $\begin{array}{l}\text { Bir ihtiyacı belirleyerek, iş fikrine ve fırsata çeviren ve } \\
\text { ortaya çıkabilecek riskleri üstlenip ticari bir işletme kuran } \\
\text { kişidir. }\end{array}$ \\
\hline
\end{tabular}

Kaynak: Karasakal ve diğ., 2013:137; Yıldırım ve diğ. 2011:192-193; Ören ve Biçkes, 2011:71

Tablo 1'de verilen tanımlar dikkate alındığında girişimci kavramının girişimcilerin; işletme sahibi olup olmamasına ve herhangi bir işyerinde fiilen çalışıp çalışmamasına bakılmaksızın bulunduğu herhangi bir ortamda ya da üstlendiği herhangi bir rolde mevcut durumun işleyişini olumlu anlamda değiştiren bireyler olarak kabul edildikleri anlaşılmaktadır. 
Tablo 2 .

Araştırmacılara Göre “Girişimcilik" Tanımları

\begin{tabular}{|c|c|}
\hline Yazar & Tanım \\
\hline $\begin{array}{c}\text { Morrison } \\
(2000)\end{array}$ & $\begin{array}{l}\text { Ekonomik bir eylem olmanın ötesinde, çok daha bütünsel } \\
\text { anlamlar ve eylemler bütünü olarak; somut ve soyut } \\
\text { argümanlarla, düşünsel ve pratik eylemlerin tümüdür. }\end{array}$ \\
\hline $\begin{array}{l}\text { Top } \\
(2006)\end{array}$ & $\begin{array}{l}\text { Girişimcinin ortaya koyduğu düşünsel ve davranışsal } \\
\text { eylemlerin, oluşturmuş olduğu örgütün ve tüm bunların } \\
\text { neticesindeki çıtıların ortak ismidir. }\end{array}$ \\
\hline $\begin{array}{c}\text { Yalçıntaş } \\
\text { (2007) }\end{array}$ & $\begin{array}{l}\text { Girişimcilik, "insanın düşünsel emeğinin ekonomik değere } \\
\text { dönüşmesi" yanında yaratıcılık, yenilik, fırsatların peşinde } \\
\text { koşmak ve risk almaktır. }\end{array}$ \\
\hline $\begin{array}{l}\text { Noruzi ve } \\
\text { di ̌̆. } \\
(2010)\end{array}$ & $\begin{array}{l}\text { Ürün ve hizmetler için sürekli yeni pazar firsatları } \\
\text { oluşturmak, ürün ve hizmetlerde günün ihtiyaçlarına cevap } \\
\text { verebilecek yenilikler oluşturmak ve bu yenilikleri } \\
\text { müşteriler ile paylaşma sürecidir. }\end{array}$ \\
\hline $\begin{array}{l}\text { Lee ve } \\
\text { Hsieh } \\
(2010)\end{array}$ & $\begin{array}{l}\text { Girişimcilik, sosyal fayda çerçevesinde ürün ve süreçlerde } \\
\text { yeniliği korumak, riski üzerine almak, pazar ve çevre } \\
\text { koşullarına uygun güncel strateji ve politikalar } \\
\text { geliştirmektir }\end{array}$ \\
\hline
\end{tabular}

Risk Alma

Eğilimi Ve

Başarma

İhtiyacının

Girişimcilik

Potansiyeline

Etkisi:

Üniversite

Öğrencileri

Üzerine Bir

Araştırma

Kaynak: Ören ve Biçkes, 2011:71; Yıldırım ve diğ., 2011: 193

Tablo 2'te yapılan açıklamalar ışığında ancak sürekli olarak mevcut durumun ötesine geçebilecek yenilikler ve değerler ortaya koyabilen bireylerin girişimcilik sıfatını devamlı olarak üzerlerinde bulundurabilecekleri söylenebilir (Ören ve Biçkes, 2011:71). Girişimcilik bir süreç olarak ele alındığında ise girişimciden, pazar fırsatlarını araştırması, yenilikçi bir davranış sergilemesi ve söz konusu fırsatlardan yararlanmak için gerekli olan kaynakları bir araya getirmesi umulmaktadır (Mykletun ve Gyimothy, 2009:3).

\subsection{Girișimci Kișilik Özellikleri}

Girişimciliğe yönelik kişilik teorisi, bireylerin sahip olduğu kişilik özelliklerinin gerçekleştirdikleri davranışları açılayabildiğini ortaya atmaktadır. En basit haliyle bu teori; bireyleri girişimci davranışlar ortaya koyması yönünde etkileyen bir özellik ya da özellikler demetinin olduğunu belirtmektedir. Genellikle öne sürülen girişimci kişilik özellikleri ise, başarma güdüsü, risk yüklenme arzusu, kontrol etme isteği, kendine güven ve belirsizlikten kaçınma olarak belirtilmektedir. Diğer kişilik teorileri ise, 
Risk Alma Eğilimi Ve

Başarma İhtiyacının Girişimcilik Potansiyeline Etkisi: Üniversite Öğrencileri Üzerine Bir Araştırma

126 değişik özelliklerin bileşimlerini dikkate almaktadır (Chell ve diğ. 1991: 2930).

Girişimcilikle ilgili yapılan araştırmalarda başarılı girişimcilerin bazı ortak özellikleri olabileceği vurgulanmaya çalışılmıştır. Ancak çalışmanın bağlamı ve kapsamı literatürde ifade edilen bütün girişimcilik özelliklerini (Arıkan, 2004: 47-49; Aytaç, 2006: 142-147; Çelik ve Akgemci, 2007; Erdoğmuş, 2004: 27-35; Gürol ve Atsan, 2006: 28-30; Koh, 1996: 13- 16; Ören ve Biçkes, 2011:72) burada ele almayı imkansız kılmaktadır. Bu nedenle bu araştırmanın bağlamı dikkate alınarak girişimciliği ortaya çıkaran kişilik özelliklerinden literatürde üzerinde sıkça durulan girişimcilik potansiyeli, risk alma ve başarma ihtiyacı özelliklerine değinilecektir.

\section{Risk Alma}

Hofstede (1991) risk kavramını; bir olay, olgu ya da fenomenin gerçekleşme olasılığının oranı olarak tanımlarken (Erdem, 2001: 44); Davidsson (2010), istenmeyen sonuçlarla karşılaşma olasılığ olasılıkları kullanan sayısal bir olgu olarak tanımlar. Balıkçı (2009) ise riski; arzu edilmeyen bir olay veya etkinin ortaya çıkması olasılığı olarak ifade eder. Bu bağlamda risk kavramı, hali hazırda gerçekleşmekte olan bir olay, olgu ya da fenomenin neticesinin kesin bir belirlilikle tanımlanamaması olarak da ifade edilebilir (Erdoğmuş, 2004: 30). Risk alma ise; sonuçların ne olacağını bilmeden, bilinmeyen bir bölgede ya da bilinmeyen koşullarda karar vermeyi içermektedir (Wakkee ve diğ. 2010). Ekonomik hayatta ise risk; ortamın yapısında var olan yüksek belirsizlik nedeniyle, potansiyel bir kazancı oluşturmanın esas alındığ 1 kararlarda, zararla karşılaşma ihtimalini ifade eder (Brindley, 2005: 145, Bozkurt ve Erdurur,2013:60). Girişimci risk, beklenen getirinin maksimum olacağına inanç ve akılcı karar verme yoluyla girişimi gerçekleştirmeyi içerir. İş alanı hakkında deneyim, girişimci içgüdüler göz önüne alındığında girişimcilerin üstlenmeyi göze aldığ1 risk miktarında önemli rol oynar (Busenitz, 1999, akt. Ceylan ve Demircan, 2002: 6).

Girişimciliğin tanımı risk üstlenme eylemine dayalı olduğundan girişimcilik faaliyetinde bulunan bir girişimci risk üstlenirken istediği sonuçları elde edebileceği gibi hayal kırıklığı yaşama durumuyla da karşı karşıya kalabilir ve söz konusu bu durum girişimci tarafından ortadan kaldırılabilecek bir durum değildir. Bu noktada üzerinde durulması gereken konu hesaplanabilir ve kabul edilebilir bir düzeyde risk alma yolunu seçmektir (İşcan ve Kaygın,2011:447; Erdem, 2001:46). 


\section{Başarma İhtiyacı}

Risk Alma

Toplumların gelişmesi ve ekonomik gelişmelerin gerçekleştirilmesinde önemli bir itici güç olma özelliği taşıyan başarma ihtiyacı, herhangi bir işin başarılı bir şekilde sonuçlandırılması için temel belirleyicilerden biridir (Hansemark, 2000: 634).

Girişimcilik davranışını uzun dönemli bir şekilde etkileyen ve önemli bir faktör olarak karşımıza çıkan başarma ihtiyacı; yüksek ve güçlü başarma ihtiyacı ile güdülenmiş bireylerin, başarılı olmak için gerekli olan motivasyona sahip olmaları ve diğer bireylerle karşılaştırıldığında girişimciliğe yönelik davranışları sergilemeleri potansiyelinin yüksek olması olarak ifade edilir (Koh, 1996: 14; Ören ve Biçkes, 2011:73).

Yüksek başarı ihtiyacına sahip bireyler, davranışlarının sonuçlarına katlanma ve sorunları çözme sorumluluğuna sahiptir. Durumları analiz eder, başarı olasılıklarını araştırır, zorlukları aşmak ve risk alma arzularına sahiptirler. Aynı zamanda bu bireyler, olaylara daha fazla odaklanmakta ve olayları değişim potansiyeline göre yorumlamaktadırlar (Champoux, 1996: 180; akt. Ceylan ve Demircan,2002:4).

\section{Girişimcilik Potansiyeli}

Girişimcilik potansiyeli, girişimcinin başarılı olabilme ihtimalini ifade eder. Burada başarı beklentisi girişimcinin azmi, enerjisi, mali gücü, bilgi ve tecrübe birikimi gibi özellikleri ile ilişkilidir. Başarı büyük ölçüde genel ve yakın çevresel faktörlerin etkisi altında olsa bile, girişimcinin başarı beklentisi olarak ifade edilen girişimcilik potansiyeli, büyük ölçüde sahip olduğu yukarıda sözü edilen kişisel özelliklere dayalıdır (Alpkan ve diğ., 2002). Girişimcilik potansiyeli, girişimcinin vizyonunu ve misyonunu belirlemesinin yanı sıra, değişimlerin ortaya çıkardığ algılamasını ve değerlendirmesini, başarma duygusunu ve gerçekleştirmek istediği işi maddileştirirken sosyal çevresini dikkate almasını ve organize etmesini (şebekeler kurmasını) gerektirir (Ören ve Biçkes, 2011:74).

Girişimciler içinde bulundukları piyasayı çok iyi takip ederler ve ortaya çıkabilecek fırsatları kollarlar. Girişimcilerin fırsatçılık yönü, yaşantıya açık olma faktörüyle bağlantılı olarak da düşünülebilir. Yapılan araştırmalar, yaşantıya açık olma faktörünün; geleneksel olmama, sempatiklik, esneklik, yüksek değişim ihtiyacı, geniş ilgi alanı, algılama kabiliyeti, belirsizliğe tahammül etme, zoru tercih etme, heyecan arama gibi faktörlerle bağlantılı olduğunu ortaya çıkarmıştır (Slick, 1999; Smith, 1999, akt. Ceylan ve Demircan,2002:7). 
Risk Alma

Eğilimi Ve

Başarma

İhtiyacının

Girişimcilik

Potansiyeline

Etkisi:

Üniversite

Öğrencileri

Üzerine Bir

Araştırma

128

\section{HIPOTEZLERIN OLUŞTURULMASI}

Norton Jr. ve Moore (2006) yaptıkları çalışmada, risk alma yeteneğinin girişimcilerin önemli bir özelliği olduğunu ve girişimci olanların, girişimci olmayanlara göre, daha fazla risk aldıklarını belirtmektedir. Yapılan çalışmaların bir kısmında, girişimcilerin diğerlerine göre daha fazla risk aldıkları savunulurken, diğer bazı çalışmalarda ise girişimcinin aşırı risk üstlenmesinin bir mit olduğu, bunun yerine, girişimcinin aslında riski yönettiği vurgulanmaktadır (Erdem, 2001:44;Ören ve Biçkes, 2011:73).

McClelland (1961) 'n öğrenilmiş ihtiyaçlar teorisine göre başarma ihtiyacı, kişinin bir işi daha iyi ve daha verimli yapma, problemleri çözme ya da karmaşık görevlerde ustalaşma arzusudur. Yüksek başarı ihtiyacına sahip bireyler, davranışlarının sonuçlarına katlanma, sorunları çözme, durumları analiz etme, başarı olasılıkların araştırma, zorlukları aşma ve risk alma sorumluluk ve arzusuna sahiptirler. Aynı zamanda bu bireyler, olaylara daha fazla odaklanırlar ve olayları değişim potansiyeline göre değerlendirebilirler (Koh, 1996, akt. Bozkurt ve Erdurur, 2013:60). Girişimcilerin başarı ihtiyaçlarını inceleyen Stormer ve diğ. (1999), McClelland'ın (1961) görüşlerine ek olarak, yüksek başarı güdüsünün yöneticiler ve üniversite öğrencilerine kıyasla, girişimcilerde daha yüksek olduğunu bu yüzden başarı güdüsünün esasen bir girişimcilik özelliği olduğunu belirtmektedirler (Ceylan ve Demircan, 2002; Ören ve Biçkes, 2011: 74). Ayrıca, ekonomik kalkınma, ekonomik ilerleme ve işletmelerin büyümesi için kritik öneme sahip olan başarı güdüsü, girişimciliğin en yaygin belirleyicilerinden birisidir (Pillis ve Reardon, 2007).

Girişimcinin başarılı olabilme ihtimali olarak tanımlanan girişimcilik potansiyeli; girişimcinin vizyonunu ve misyonunu, değişimlerin yarattığı firsatları fark edip değerlendirmesini, başarma duygusunu, gerçekleştirmek istediği işi somutlaştırırken sosyal çevresini göz önünde bulundurmasını ve harekete geçirmesini yansıtır (Ören ve Biçkes, 2011:74).

Girişimcilik potansiyeli taşıyan bireylerin özellikleri dikkate alındığında; yeniliklere açık olma, risk almaya gönüllü olma, yaratıcı, becerikli ve fırsat odaklı olma özelliklerini taşıdığından bu bireyler 'potansiyel girişimci' olarak görülmektedir (Cansız, 2007, 28).

Yukarıda belirtilen teorik açıklamalar ışığında aşağıdaki hipotezler geliştirilmiştir. 
H1: Risk alma eğilimi girişimcilik potansiyelini pozitif etkilemektedir.

H2: Başarma ihtiyacı girişimcilik potansiyelini pozitif etkilemektedir.

\section{ARAŞTIRMANIN YÖNTEMI}

Girişimci ve girişimcilik yazınına ait eleştirel literatür taraması yapılarak oluşturulan hipotezler ve Şekil 1'de sunulan araştırma modeli temel alınarak girişimci kişilik özelliklerinden risk alma ve başarma ihtiyacının, girişimcilik potansiyeline etkisini belirlemeye yönelik olarak gerçekleştirilen bu çalışma; bir devlet üniversitesin meslek yüksekokulunda öğrenim gören öğrencilerden elde edilen veriler $(n=475)$ 1şı̆̆ında istatistiki analizler gerçekleştirilerek hipotezler test edilmiştir. Bu kapsamda ilk olarak daha önce Türk kültürüne uyarlama çalışmaları yapılan ve araştırmada kullanılan risk alma eğilimi, başarma ihtiyacı ve girişimcilik potansiyeline ait ölçeklerin, araştırma verilerine uygunluğunu test etmek amacıyla Doğrulayıcı Faktör Analizi yapılmıs ve değişkenler arası korelasyonlar tespit edilmiştir. İkinci olarak ise araştırmanın hipotezlerinin test edilmesi amacıyla Çoklu Regresyon Analizi gerçekleştirilmiştir.

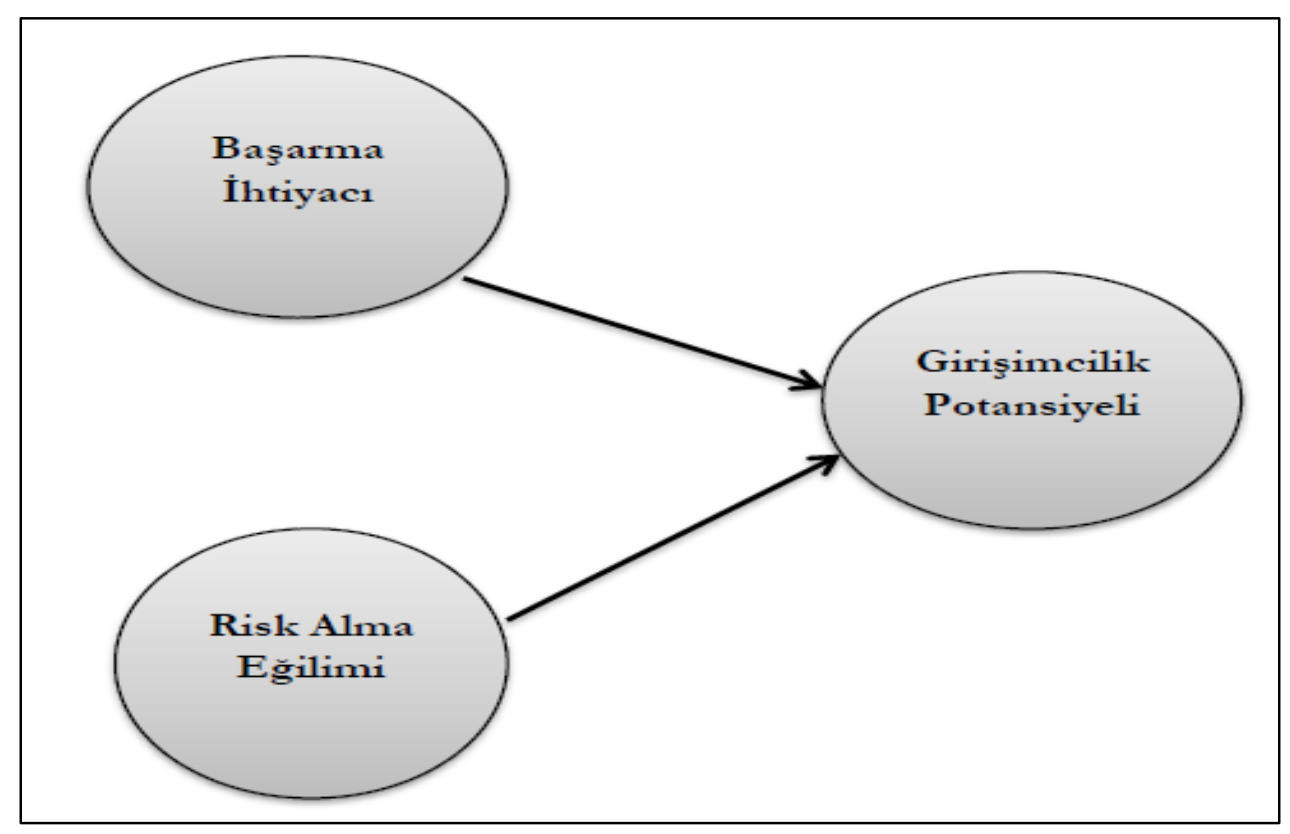

Şekil 1: Araştırma Modeli 
Risk Alma

Eğilimi Ve

Başarma

İhtiyacının

Girişimcilik

Potansiyeline

Etkisi:

Üniversite

Öğrencileri

Üzerine Bir

Araştırma

130

\subsection{Araştırmanın Evreni ve Örneklemi}

Araştırma evrenini bir devlet üniversitesine ait meslek yüksekokulunda öğrenim gören öğrenciler oluşturmaktadır. Ana kütleyi oluşturan ve 2015-2016 akademik y1lında öğrenim gören 2.000 meslek yüksekokulu öğrencisi göz önünde bulundurularak \%95 güven aralığında \%5'lik bir hata payı dikkate alınarak minimum örneklem büyüklüğü 323 kişi olarak hesaplanmıştır (Sekaran, 1992:253). Tam sayım yapmak amacıyla gönüllük esasına göre doldurulması istenen anket formaları tüm öğrencilere fiziki ve online olarak (mail yoluyla) dağıtılmıştır. Fiziki ve online (mail yoluyla) dağıtımı yapılan anket formalarından geri dönüşü sağlanan; hatalı ve eksik olarak doldurulmuş olan anket formaları elenerek 475 geçerli anketin analiz yapmak için uygun olduğu kanaatine varılmıştır.

Araştırmaya katılanların \%50,5'i erkek $(n=240)$ ve \%51,2'sinin $(n=243)$ anne ve/veya babası kendi işine sahip değildir. Ayrıca katılımcıların \%49,3'ünün $(n=234)$ annesinin ilköğretim mezunu ve $\% 56,6$ 'sının (n=269) babasının ilköğretim mezunu olduğu, \%66,3'ünün ( $n=315)$ ailesinin Güneydoğu Anadolu Bölgesinde ikamet ettiği ve $\% 62,9^{\prime}$ unun aylık aile gelirinin $0.00 \mathrm{TL}-2.000 \mathrm{TL}$ arasında yer aldığ 1 tespit edilmiştir.

\subsection{Araştırmada Kullanılan Ölçekler}

Üniversite öğrencilerinde girişimci kişilik özelliklerinden risk alma ve başarı ihtiyacının girişimcilik potansiyeline etkisini belirlemeye yönelik olan bu araştırmada kullanılan ölçeklere ilişkin bilgiler aşağıda verilmektedir. Araştırmada kullanılan ölçeklere ilişkin uyum iyiliği değerleri Tablo 4'de sunulmuştur. Araştırmanın modelini ve hipotezlerini test etmek amacıyla Çoklu Regresyon Analizi yapılmıştır. Gizil değişkenlerle analiz yapabilmek için araştırmadaki tüm değişkenlerin ölçülmesinde kullanılan bütün ölçüm araçlarının geçerli ve güvenilir olması gerektiğinden (Şimşek, 2007:19) araştırmada kullanılan risk alma eğilimi, başarma ihtiyacı ve girişimcilik potansiyeline ait ölçeklere ilişkin yapılan geçerlilik ve güvenilirlik çalışmalarına dair sonuçlar her ölçekle ilgili bölümün sonunda sunulmuştur. Tüm ölçeklerde KMO (Kaiser-MeyerOlkin) ve Barlett testleri kabul edilen standartlardadır (Malhotra, 1996, akt. Altunışık ve diğ. 2012: 268). Ayrıca ölçeklerde çoklu bağlantı testleri yapılmış olup bağlantı problemi bulunmamaktadır

\section{Risk Alma Ĕ̆ilimi Ölçeği (RAE)}

$\mathrm{Bu}$ araştırmada risk alma eğilimini ölçmek amacıyla Hisrich ve Peters'ten uyarlanarak; Alpkan, Keskin ve Zehir (2002) tarafından 
kullanılmış olan ve Ören ve Biçkes (2011)'den yararlanılarak oluşturulan Risk Alma Eğilimi Ölçeği (RAE) kullanılmıştır. Tek boyutlu bir yapıya sahip olan ve 6 maddeyi kapsayan bu ölçek, 5'li Likert tipi ifadeden (1=Hiç Katılmıyorum, 5= Tamamen Katılıyorum) oluşmaktadır.

Ölçeğin yapı geçerliliğini test etmek amacıyla AMOS 23.0 paket program ile Doğrulayıcı Faktör Analizi yapılmıştır. Faktör analizi neticesinde ölçeğin tek boyutlu yapıya uyum sağlamadığ değerlerinin kabul edilebilir standartlarda olmadığı tespit edildiğinden ifadelerin standardize edilmiş regresyon katsayılarına (Standardized Regression Weights) değerlendirilmiştir. Tahmin (estimate) değerleri çok düşük olduğu görülen RAE2 (Bir şeyi daha önce başkası/başkaları denememişse ben de denemem.) ve RAE6 (Kasıtlı olarak hiç bilmediğim bir yola sapabilirim.) ifadeleri sırasıyla analizden çıkarılarak Doğrulayıcı Faktör Analizi (DFA) tekrarlanmıştır.

Ayrıca birbiri arasındaki kovaryans değeri çok yüksek olan RAE-3 (Hiç tanımadığım birine gidip sohbete başlayabilirim.) ve RAE-5 (Son altı ay içinde sahip olduklarımı kaybetmeme neden olabilecek bazı riskler aldım.) ifadeleri arasında modifikasyon uygulaması gerçekleştirilmiştir.

Gerçekleştirilen işlemlerin ardından tekrarlan nihai Doğrulayıcı Faktör Analiz (DFA) neticesinde, verilerin ölçeğin tek boyutlu yapısına uyum sağladığı tespit edilmiş ve ölçeğe ait uyum iyiliği değerleri, diğer ölçeklerin uyum iyiliği değerleri ile birlikte Tablo 3'de sunulmuştur.

\section{Başarma İhtiyacı Ölçeği (Bí)}

Başarma ihtiyacını ölçmek amacıyla Bandırma İktisadi Araştırmalar Enstitüsü (2007:51-52) tarafından Bandırma'nın Girişimcilik Profilini ortaya çıkarmak için gerçekleştirilen çalışmada kullanılmış olan ve Ören ve Biçkes (2011)'den yararlanılarak oluşturulan Başarma İhtiyacı Ölçeği (Bİ) kullanılmıştır. Tek boyutlu bir yapıya sahip olan ve 6 maddeyi kapsayan bu ölçek, 5'li Likert tipi ifadeden (1=Hiç Katılmıyorum, 5= Tamamen Katılıyorum) oluşmaktadır.

Ölçeğin yapı geçerliliğini test etmek amacıyla AMOS 23.0 paket program ile Doğrulayıcı Faktör Analizi yapılmıştır. Faktör analizi neticesinde ölçeğin tek boyutlu yapıya uyum sağlamadığ değerlerinin kabul edilebilir standartlarda olmadığı tespit edildiğinden ifadelerin standardize edilmiş regresyon katsayılarına (Standardized Regression Weights) değerlendirilmiştir. Tahmin (estimate) değerleri çok düşük olduğu görülen Bi்6 (Başarısızlığa uğrama düşüncesi bende sıkıntı ve
Risk Alma

Eğilimi Ve

Başarma

İhtiyacının

Girişimcilik

Potansiyeline

Etkisi:

Üniversite

Öğrencileri

Üzerine Bir

Araştırma

131

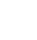


Risk Alma Eğilimi Ve

Başarma İhtiyacının Girişimcilik Potansiyeline Etkisi: Üniversite Öğrencileri Üzerine Bir Araştırma

132 endişe yaratmaz.) ifadesi analiz dışında tutularak Doğrulayıcı Faktör Analizi (DFA) tekrarlanmıştır.

Ayrıca birbiri arasındaki kovaryans değeri çok yüksek olan Bİ-3 (Kimse beğenmese de ben doğru bildiğimi savunurum.) ve Bİ-5 (Kendi şansımı kendim yaratırım) ifadeleri arasında modifikasyon uygulanmıştır.

Tüm bu işlemlerin ardından gerçekleştirilen nihai Doğrulayıcı Faktör Analiz (DFA) neticesinde verilerin ölçeğin tek boyutlu yapısına uyum sağladiğı tespit edilmiş ve ölçeğe ait uyum iyiliği değerleri, diğer ölçeklerin uyum iyiliği değerleri ile birlikte Tablo 3' de sunulmuştur.

\section{Girişimcilik Potansiyeli Ölçeği (GP)}

$\mathrm{Bu}$ araştırmada girişimcilik potansiyelini ölçmek amacıyla bir girişimcilik merkezinin (Center of Rural Entrepreneurship) Girişimci Kişilik Testi' nden uyarlanarak ve Ören ve Biçkes (2011)'den yararlanılarak oluşturulan Girişimcilik Potansiyeli Ölçeği (GP) kullanılmıştır. Tek boyutlu bir yapıya sahip olan ve 12 maddeyi kapsayan bu ölçek, 5'li Likert tipi ifadeden (1=Hiç Katılmıyorum, 5= Tamamen Katılıyorum) oluşmaktadır.

Ölçeğin yapı geçerliliğini test etmek amacıyla AMOS 23.0 paket program ile Doğrulayıcı Faktör Analizi yapılmıştır. Faktör analizi neticesinde ölçeğin tek boyutlu yapıya uyum sağlamadığı ve uyum iyiliği değerlerinin kabul edilebilir standartlarda olmadığı tespit edildiğinden ifadelerin standardize edilmiş regresyon katsayılarına (Standardized Regression Weights) değerlendirilmiştir. Tahmin (estimate) değerlerinin normal olduğu sonucuna varılması neticesinde uyum iyiliği değerlerini kabul edilebilir standartlara taşımak için birbiri arasındaki kovaryans değeri çok yüksek olan GP-3 (Yeni fikirlerle nasıl daha iyi ve daha etkili olunabileceği ile ilgili olarak sık sık gündeme gelirim.) ile GP-6 (Ticari değere sahip olan iş fırsatlarını sürekli olarak görebilirim); GP-7 (Meydan okumalara (rekabete) ve problemlere çözüm bulmak için gereken yaratıcılığa sahibim.) ile GP-9 (Başarmak istediğini gerçekleştirmek için sıkı çalışan biriyim) ve GP-8 (Meydan okumalara (rekabete) ve problemlere çözüm bulmak için gereken beceriye sahibim.) ile GP-7 (Meydan okumalara (rekabete) ve problemlere çözüm bulmak için gereken yaratıcılığa sahibim.) ifadeleri arasında modifikasyon uygulanmıştır.

Tüm bu işlemlerden sonra tekrarlan nihai Doğrulayıcı Faktör Analiz (DFA) neticesinde verilerin ölçeğin tek boyutlu yapısına uyum sağladığ tespit edilmiş ve ölçeğe ait uyum iyiliği değerleri, diğer ölçeklerin uyum iyiliği değerleri ile birlikte Tablo 3' de sunulmuştur. 
Üniversite öğrencilerinin risk alma eğilimi, başarama ihtiyacı ve girişimcilik potansiyellerini ölçmek amacıyla kullanılan her bir ölçeğe ait güvenirlilik analizleri gerçekleştirilmiş elde edilen Cronbach's Alpha güvenilirlik katsayıları Tablo 4'te sunulmuştur. Söz konusu ölçeklere ait faktör analizinin uygunluğunu gösteren KMO (Kaiser-Meyer-Olkin) değerleri kritik değer olan 0,70'in üzerinde hesaplanmış, Barlett testi sonuçları ise anlamlı $(\mathrm{p}=.000)$ olarak bulunmuştur (Malhotra, 1996, akt. Altunışık ve diğ. 2012: 268)

\subsection{Araştırmanın Bulguları}

Girişimcilik özelliklerine ait risk alma eğilimi ve başarma ihtiyacının girişimcilik potansiyeline etkisinin incelendiği bu çalışmada kullanılan ölçeklere ilişkin gerçekleştirilen doğrulayıcı faktör analizi sonuçlarına ait bulgular Tablo 3' de sunulmuştur.

Risk Alma

Eğilimi Ve

Başarma

İhtiyacının

Girişimcilik

Potansiyeline

Etkisi:

Üniversite

Öğrencileri

Üzerine Bir

Araştırma

133

Tablo 3.

Ölçeklerin Uyum İyiliği Değerleri*

\begin{tabular}{|c|c|c|c|c|c|c|c|c|}
\hline Ölçekler & $\mathbf{X}^{2}$ & $\mathrm{df}$ & $\begin{array}{l}\mathrm{CMIN} / \\
\mathrm{DF} \leq 5\end{array}$ & $\begin{array}{l}\text { GFI } \\
\geq .90\end{array}$ & $\begin{array}{c}\text { AGFI } \\
\geq .90\end{array}$ & $\begin{array}{l}\text { CFI } \\
\geq .90\end{array}$ & $\begin{array}{l}\text { NFI TLI } \\
\geq .90 \geq .90\end{array}$ & $\begin{array}{c}\text { RMSEA } \\
\leq .08\end{array}$ \\
\hline $\begin{array}{l}\text { 1. Başarma } \\
\text { İhtiyacı }\end{array}$ & 12.94 & 4 & 2.23 & .99 & .96 & .99 & $\begin{array}{ll}.98 & .97\end{array}$ & .07 \\
\hline $\begin{array}{l}\text { 2.Risk Alma } \\
\text { Eğilimi }\end{array}$ & 2.29 & 1 & 2.30 & .99 & .98 & .99 & $\begin{array}{ll}.99 & .96\end{array}$ & .05 \\
\hline $\begin{array}{l}\text { 3.Girişimcilik } \\
\text { Potansiyeli }\end{array}$ & 194.98 & 51 & 3.82 & .93 & .89 & .95 & $.94 \quad .94$ & .07 \\
\hline
\end{tabular}

Araştırma neticesinde elde edilen verilere SPSS 23.0 ve AMOS 23.0 paket programları vasıtasıyla yapılan analizler çerçevesinde katılımcıların başarma ihtiyacı, risk alma eğilimi ve girişimcilik potansiyeli düzeylerine ilişkin verilerin ortalamaları, standart sapmaları ve aralarındaki korelasyonlar incelenmiş ve Tablo 4 'te sunulmuştur. 
Risk Alma

Eğilimi Ve

Başarma

İhtiyacinın

Girişimcilik

Potansiyeline

Etkisi:

Üniversite

Öğrencileri

Üzerine Bir Araştırma

134

Tablo 4.

Değişkenlere Ait Ortalama, Standart Sapma ve Korelasyon Katsayıları

\begin{tabular}{lccccc}
\hline Değişkenler & Ort. & S.S & $\mathbf{1}$ & $\mathbf{2}$ & $\mathbf{3}$ \\
\hline 1.Başarma İhtiyacı & 3,69 &, 969 & $(.813)$ &, $531^{* *}$ &, $637^{* *}$ \\
\hline 2.Risk Alma Eğilimi & 3,35 &, 893 &, $531^{* *}$ & $(.570)$ &, $629^{* *}$ \\
\hline $\begin{array}{l}\text { 3.Girişimcilik } \\
\text { Potansiyeli }\end{array}$ & 3,87 &, 848 &, $637^{* *}$ &, $629^{* *}$ & $(.926)$
\end{tabular}

Not: Alpha güvenilirlik katsayıları parantez içinde gösterilmiştir. ${ }^{* *} \mathrm{p}<.01$

Üniversite öğrencilerinde girişimci kişilik özelliklerinden risk alma ve başarı ihtiyacı ile girişimcilik potansiyeline arasındaki ilişkiler çoklu korelasyon analizi ile araştırılmıştır.

Elde edilen bulgulara göre; katılımcıların başarma ihtiyacı düzeyi ile girişimcilik potansiyeli arasında anlamlı ve pozitif yönlü bir ilişki vardır ( $\mathrm{r}(475)=.637, \mathrm{p}<.001)$; katılımcıların risk alma eğilimi düzeyi ile girişimcilik potansiyeli arasında arasında anlamlı ve pozitif yönlü bir ilişki vardır ( $r(475)=.629, p<.001)$ (Gürbüz ve Şahin, 2016:268).

Analizin ikinci aşamasında ise hipotezlerin test edilmesi amacıyla Çoklu Regresyon Analizi yapılmıştır.

Adıyaman Üniversitesi Besni Meslek Yüksekokulu'nda öğrenim gören öğrencilerin girişimcilik potansiyellerini, girişimci kişilik özelliklerinden olan başarma ihtiyacı ve risk alma eğilimi düzeylerinin ne kadar belirlediğini incelemek üzere çoklu doğrusal regresyon analizi gerçekleştirilmiştir. Analiz neticesinde elde edilen ortalamalar, standart sapmalar ve korelasyon değerleri Tablo $4^{\prime}$ te sunulmuştur. Çoklu Regresyon Analizi sonuçları ise Tablo 5'de sunulmuştur.

Tablo 5.

Çoklu Regresyon Analizi Sonuçları

\begin{tabular}{lccc}
\hline Değişkenler & B & S.H. & $\beta$ \\
\hline 1.Başarma İhtiyacı &, 37 &, 03 &, $42^{* *}$ \\
\hline 2.Risk Alma Eğilimi &, 39 &, 04 &, $41^{* *}$ \\
\hline Sabit & 1,224 &, 119 & \\
\hline Not: $\mathrm{R}^{2}=0.52 \cdot$ Düz $\mathrm{R}^{2}=0.52 \cdot \mathrm{F}_{(2,472)}=259,114, \mathrm{p}<0.001^{* *} \mathrm{p}<.01$ &
\end{tabular}


Tablo 5'değerlendirildiğinde çoklu regresyon analizi sonuçlarının istatistiksel olarak anlamlı olduğu görülmektedir. $\left(F_{(2,472)}=259,114, \mathrm{p}<0.001\right)$ Düzeltilmiş $R^{2}$ değeri $0.52^{\prime}$ dir. Bu netice, girişimcilik potansiyelindeki $\% 52$ 'lik orandaki varyansın girişimci kişilik özelliklerinden olan başarma ihtiyacı ve risk alma eğilimi tarafından açıklandığını göstermektedir. Tablodaki Beta katsayıları incelendiğinde, tüm bağımsız değişkenler regresyon analizine tabi tutulduğunda, girişimcilik potansiyelini açıklamada girişimci kişilik özelliklerinden başarma ihtiyacı ( $\beta=0.42$, $\mathrm{p}<0.01)$ ve risk alma eğiliminin $(\beta=0.41, \mathrm{p}<0.01)$ anlamlı katkısının olduğu ortaya çıkmaktadır (Gürbüz ve Şahin, 2016:279-280)

$\mathrm{Bu}$ durumda; girişimci kişilik özelliklerinden olan başarma ihtiyacının, girişimcilik potansiyeline etkisini araştıran $\mathrm{H} 1$ hipotezi ve girişimci kişilik özelliklerinden olan risk alma eğiliminin, girişimcilik potansiyeline etkisini araştıran $\mathrm{H} 2$ hipotezi kabul edilmiştir.

Risk Alma

Eğilimi Ve

Başarma

İhtiyacının

Girişimcilik

Potansiyeline

Etkisi:

Üniversite

Öğrencileri

Üzerine Bir

Araştırma

135

Tablo 6.

Hipotez Testi Sonuçları

\begin{tabular}{cccc}
\hline & Hipotez & $\beta^{*}$ & Sonuç \\
\hline H1 & Başarma İhtiyacı $\rightarrow$ Girişimcilik Potansiyeli &, $42^{* *}$ & Kabul \\
\hline H2 & Risk Alma Eğilimi $\rightarrow$ Girişimcilik & $41^{* *}$ & Kabul \\
\hline
\end{tabular}

*Standardize edilmiş katsayılar. ${ }^{* *} \mathrm{p}<.01$

\section{V.TARTIŞMA VE SONUÇ}

Girişimci kişilik özelliklerinden başarma ihtiyacı ve risk alma eğiliminin, girişimcilik potansiyeline etkisini incelemek amacıyla gerçekleştirilen ve geleceğin potansiyel girişimcileri olan üniversite öğrencileri örnekleminde ele alan bu araştırma kapsamında test edilen her 2 (iki) hipotez kabul edilerek desteklenmiştir.

McClelland (1961) öğrenilmiş ihtiyaçlar teorisinde başarma ihtiyacını kişinin bir işi daha iyi ve daha verimli yapma, problemleri çözme ya da karmaşık görevlerde ustalaşma arzusu olarak tanımlamıştır. Ceylan ve Demircan (2002); Ören ve Biçkes (2011) ise, yüksek başarı güdüsünün yöneticiler ve üniversite öğrencilerine kıyasla, girişimcilerde daha yüksek olduğunu bu yüzden başarı güdüsünün esasen bir girişimcilik özelliği olduğunu belirtmişlerdir. Araştırma neticesinde başarma ihtiyacının girişimcilik potansiyeline pozitif ve anlamlı olarak etki ettiğinin tespit edilmesi yazını doğrular niteliktedir. Norton Jr. ve Moore (2006) risk alma 
Risk Alma Eğilimi Ve Başarma İhtiyacının Girişimcilik Potansiyeline Etkisi: Üniversite Öğrencileri Üzerine Bir Araştırma

136 yeteneğinin girişimcilerin önemli bir özelliği olduğunu belirtmekte ve girişimci olan bireylerin, girişimci olmayanlara nazaran daha fazla risk aldıklarını ortaya atmaktadır. Nitekim bu araştırma neticesinde de risk alma eğiliminin girişimcilik potansiyeline pozitif ve anlamlı olarak etki ettiğinin tespit edilmesi önceki araştırmacıları ve genel kanıyı destekler niteliktedir.

Bugünün gençleri olan üniversite öğrencileri yarının yetişkinleri ve potansiyel iş adamları/kadınları olma yolunda ilerlemektedir. Araştırmanın sonuçlarının başarma ihtiyacı ve risk alma eğiliminin girişimcilik potansiyelini pozitif ve anlamlı olarak etkilediğini ortaya koymasından hareketle ve kamu ve özel sektörün de üniversiteden mezun olan tüm bireyleri istihdam etme şansının olmadığı göz önünde bulundurulduğunda yarının girişimcilerini oluşturabilmek için bugünden gerekli tedbirleri almak gerektiği kanısına ulaşmak oldukça rasyoneldir.

$\mathrm{Bu}$ çerçevede başta yükseköğrenim eğitimi veren üniversiteler olmak üzere, girişimcilik ile ilgili kamu kuruluşları, sivil toplum kuruluşları, Sanayi/Ticaret Odaları vb. kişi/örgütlerin gençlerin girişimcilik potansiyeline risk alma ve başarma ihtiyacı perspektifinden bakmalarının yararlı olacağı düşünülmektedir.

Son olarak; girişimci kişilik özelliklerinden olan başarma ihtiyacı ve risk alma eğiliminin üniversite öğrencilerinin girişimcilik potansiyeline etkilerinin araştırıldığı bu çalışmanın; mevcut girişimciler üzerinde ve sektör, karlılık oranı, çalışan personel sayısı, üretim/satış miktarı vb. değişkenler kullanılarak yapılacak farklılık testlerini de barındıran araştırmalarla genişletilmesi araştırmacılara tavsiye edilmektedir.

\section{KAYNAKÇA}

Alpkan, L., Keskin, H. ve Zehir, C. (2002). Girişimcilik Hisleriyle Girişimcilik Potansiyeli Arasındaki İlişki: Gebze ve Civarındaki Girişimciler Üzerine Bir Saha Araştırması, 21. Yüzyılda KOBI'ler: Sorunlar, Fırsatlar ve Çözüm Önerileri Sempozyumu, Doğu Akdeniz Üniversitesi İşletme Fakültesi, K.K.T.C.

Altunışık, R., R. Coşkun, S. Bayraktaroğlu, ve E. Yıldırım. (2012). Sosyal Bilimlerde Araştırma Yöntemleri. Geliştirilmiş 7. Baskı. Sakarya: Sakarya Yayıncilik.

Arıkan, S. (2004). Girişimcilik Temel Kavramlar ve Bazı Güncel Konular. Ankara: Siyasal Kitabevi. 
Aytaç, Ö. (2006). Girişimcilik: Sosyo-Kültürel Bir Perspektif. Dumlupınar Üniversitesi Sosyal Bilimler Dergisi, 15: 139-160.

Balıkçı, Y. (2009). İşletmelerde Risk Yönetimi. 1. Basım. İstanbul: Cinius

Bandırma İktisadi Araştırmalar Enstitüsü. (2007). Bandırma'nın Girişimcilik Profili, BİAE Araştırma İnceleme Raporu, Bandırma: Yayın No: AİR- 1/2007

Beatty, J. (1998). Peter Drucker'a Göre Dünya, Çev. Akınhay, O., İstanbul: Sistem Yayınları.

Binks, M. ve Vale, P. (1990). Entrepreneurship and Economic Change. London: McGrawHill Book Company.

Bozkurt Ö. ve Erdurur K. (2013). Girişimci Kişilik Özelliklerinin Girişimcilik Eğilimindeki Etkisi: Potansiyel Girişimciler Üzerinde Bir Araştırma. Girişimcilik ve Kalkınma Dergisi, 8(2):57-78

Brindley, C. (2005). Barriers to Women Achieving Their Entrepreneurial Potential: Women and Risk. International Journal of Entrepreneurial Behaviour $\mathcal{E}$ Research, 11(2): 144-161.

Bull, I. ve Willard, G. (1995). Towards A Theory of Entrepreneurship, Entrepreneurship. Tarrytown: Pergamon.

Busenitz, L. W. (1999). Entrepreneurial Risk and Strategic Decision Making. Journal of Applied Behavioral Science, 35: 325-341

Cansız E., (2007), Üniversite Öğrencilerinin Girişimcilik Özelliklerinin Belirlenmesi: Süleyman Demirel Üniversitesi Öğrencileri Üzerine Bir Çalışma, Yayınlanmamış Yüksek Lisans Tezi, Isparta: Süleyman Demirel Üniversitesi, Sosyal Bilimler Enstitüsü.

Ceylan A. ve Demircan N. (2002). Girişimcilerin Başarı, Güç ve Yakın İlişki İhtiyaçlarının Kişilik Özellikleriyle İlişkisi Üzerine Düzce Bölgesi'ndeki KOBİlerde Yapılan Bir Araştırma. 21. Yüzyılda KOBI'ler: Sorunlar, Fırsatlar ve Çözüm Önerileri Sempozyumu, Doğu Akdeniz Üniversitesi, http://www.emu.edu.tr/smeconf/turkcepdf/bildiri_21.pdf (10.04.2014)

Champoux, J. E. (1996). Organizatioanl Behavior, Integrating Individuals Groups and Processes, West Publising Company,

Chell, E., Haworth, J. ve Brearley, S. (1991): The Entrepreneurial Personality. New York: Routledge.

Çelik, A. ve Akgemci, T. (2007). Girişimcilik Kültürü ve KOBİler. Ankara: Gazi Kitabevi.

Çetin, C. (1996). Yeniden Yapılanma-Girisimcilik ve Küçük ve Orta Boy İşletmeler ve Bunların Özendirilmesi. İstanbul: Der Yayınları.
Risk Alma

Eğilimi Ve

Başarma

İhtiyacinın

Girişimcilik

Potansiyeline

Etkisi:

Üniversite

Öğrencileri

Üzerine Bir

Araştırma 
Risk Alma

Eğilimi Ve

Başarma

İhtiyacının

Girişimcilik

Potansiyeline

Etkisi:

Üniversite

Öğrencileri

Üzerine Bir

Araştırma

138
Çetindamar, D. (2002), Türkiye'de Girisimcilik, TUSİAD Yayınları.

Davidsson, M. (2010). Risk Management in A Pure Unit Root. The Journal of Risk Finance, 11(2): 224-234.

Emsen, Ö. (2001). Genç Nesilde Mesleki Eğilimler ve Girişimcilik: Ampirik Bir Çalışma. MPM Verimlilik Dergisi, 1:153-176.

Erdem, F. (2001). Girişimcilerde Risk Alma Eğilimi ve Belirsizliğe Tolerans İlişkisine Kültürel Yaklaşım. Akdeniz Üniversitesi İ.İ.B.F. Dergisi, (2): 43-61.

Erdoğmuş, N. (2004). Aile İşletmeleri: İkinci Kuşağın Yetiştirilmesi. İstanbul: İGİAD Yayını, No:1.

Erdurur, K., (2012), Turizm Lisans Dersi Alan Öğrencilerin Girişimci Kişilik Özelliklerinin Girişimcilik Eğilimine Etkisi: Akçakoca Turizm İşletmeciliği ve Otelcilik Yüksekokulu Örneği, Yayınlanmamış Yüksek Lisans Tezi, Düzce: Düzce Üniversitesi Sosyal Bilimler Enstitüsü.

Farell, L.(1997). Girisimcilik Üzerine Dersler (Röportaj). Power Dergisi, Kasım Sayısı.

Foss, N. J. ve. Klein, P. G., (2002), Entrepreneurship and The Firm, England: Edward Elgar: Aldershot.

Girginer N. ve Uçkun N. (2004). İsletmecilik Eğitimi Alan Lisans Öğrencilerinin Girişimciliğe Bakış Açıları: Eskişehir Osmangazi Üniversitesi İ.İ.B.F İsletme Bölümü Öğrencilerine Yönelik Bir Uygulama, 3. Ulusal Bilgi, Ekonomi ve Yönetim Kongresi, 25-26 Kasım, Eskişehir.

Gürbüz S. ve Şahin F. (2016). Sosyal Bilimlerde Araştırma Yöntemleri FelsefeYöntem-Analiz, Ankara: Seçkin Yayınevi.

Gürol Y. ve Atsan N. (2006). Entrepreneurial Characteristics Amongst University Students Some Insides for Entrepreneurship Education and Training in Turkey. Education + Training, 48(1): 25-38.

Hansemark, O. C. (2000). Predictive Validity of TAT and CMPS on the Entrepreneurial Activity, "Start of a New Business: A Longitudinal Study". Journal of Management Psychology, 15(7): 634-654.

Hinterhuber, H. H. ve Wolfgang P. (1992). Are You A Strategist or Just A Manager?. Harward Business Review, January- February.

Hofstede, H. (1991) Vivre Dans Une Monde Multiculturel, Les Editions D’Organisation, Paris.

Ireland, R. D., Hitt, M. A. ve Sirmon, D. G.. (2003). A Model of Strategic Entrepreneurship: The Construct and Its Dimensions. Journal of Management, 29: 963-989. 
İşcan Ö. F. ve Kaygın E.(2011). Üniversite Öğrencilerinin Girişimcilik Eğilimlerini Belirlemeye Yönelik Bir Araştırma. Atatürk Üniversitesi Sosyal Bilimler Enstitüsü Dergisi,15 (2): 443-462

Karahan M. ve Ulusoy İ. (2010). Hatay İli Girişimcilik Özelliklerinin İncelenmesi. EKEV Akademi Dergisi, 14(43): 367-379.

Karasakal, N. K., Aksu, B. ve Demircili, R. (2013). Meslek Yüksekokullarındaki Teknik ve Sosyal Program Öğrencilerinin Girişimci Kişilik Açısında Karşılaştırılarak Program Türünün Girişimciliğe Özendirme ve Girişimci Kişilik Oluşumu Konusunda Bir Etkisinin Olup Olmadığını Tespit Etmeye Yönelik Bir Alan Araştırması. Organizasyon ve Yönetim Bilimleri Dergisi, 5(2):134-150

Koh, H. C. (1996). Testing Hypotheses of Entrepreneurial Characteristics A Study of Hong Kong MBA Students. Journal of Managerial Psychology, 11(3): 1225.

Lee J.-S. ve Hsieh C.-J.(2010). A Research in Relating Entrereneurship, Marketing Capability, Innovative Capability and Sustained Competitive Advantage. Journal of Business-Ekonomics Research, 8(9): 109-119.

Malhotra, N. K. (1996). Marketing Research. An Applied Orientation. Second Edition. New Jersey: Pearson Prentice Hall.

McClelland, D. C. (1961). The Achiving Society. Princeton: D. Van Nostrand Company.

Meredith, G. G., Robert, E. N., Philip, A. N. (1984), Girisimciliğin Uygulanması, Çeviren: Tan, S. ve Pazarcık, O., Uluslararası Çalısma Örgütü, Ankara.

Morrison, A. (2000). Entrepreneurship: What Triggers It?. International Journal of Entrepreneurial Behaviour \& Research, 6(2): 59- 71.

Mykletun R. J. ve Gyimothy S. (2009). Beyond the Renaissance of The Traditional Voss Sheep's-Head Meal: Tradition, Culinary Art, Scariness And Entrepreneurship. Tourism Management, doi:10.1016/j.tourman.2009.04.002.

Norton, JR., William, I. ve William, M. T. (2006). The Influence of Entrepreneurial Risk Assessment on Venture Launch or Growth Decisions. Small Business Economics, 26: 215-226.

Noruzi, M. R., Westover, J. H. ve Rahimi, G. R. (2010). An Exploration of Social Entrepreneuship in the Entrepreneuship Era, Asian Social Science, 6(6):3-10.

Ören K.ve Biçkes M. (2011). Kişilik Özelliklerinin Girişimcilik Potansiyeli Üzerindeki Etkileri (Nevşehir'deki Yüksek Öğrenim Öğrencileri Üzerinde Yapılan Bir Araştırma. Süleyman Demirel Üniversitesi İktisadi ve İdari Bilimler Fakültesi Dergisi, 16(3): 67-68
Risk Alma

Eğilimi Ve

Başarma

İhtiyacının

Girişimcilik

Potansiyeline

Etkisi:

Üniversite

Öğrencileri

Üzerine Bir

Araştırma

139 
Risk Alma Eğilimi Ve

Başarma İhtiyacinın Girişimcilik Potansiyeline Etkisi: Üniversite Öğrencileri Üzerine Bir Araştırma
Pillis, E. ve Reardon K. K. (2007). The Influence Of Personality Traits And Persuasive Messages on Entrepreneurial Intention A Cross-Cultural Comparison. Career Development International, 12(4): 382-396.

Sekaran, U. (1992). Research Methods for Business: A Skill Building Approach, Second Edition, John Wiley \& Sons, 450.

Slick, B.(1999). Think Thrice Before Hiring Entrepreneurs. Internet Week, February,752: 28-32,

Smith, S.S. (1999). Rebirth of A Salesman, Losing Your Edge?" Entrepreneur Magazine, January.

Stormer, F., Kline, T. ve Goldenberg, S. H. (1999). Measuring Entrepreneurship With General Enterprising Tendency Test. Criterion Validity And Reliability. Human Systems Management 18(1): 47-53.

Şenocak, B. (1992). 2000'li Yılların Girisimcilik Modeli. 3. İzmir İktisat Kongresi, 181-186, İzmir.

Şimşek, Ö. F. (2007). Yapısal Eşitlik Modellemesine Giriş: Temel İlkeler ve Lisrel Uygulamaları. Ankara: Ekinoks.

Titiz, T. (1999). Genç Girişimcilere Öneriler. İstanbul: İnkılap Kitabevi.

Titiz, T.(1994), Girisimcilik, İstanbul: İnkılap Kitapevi.

Top, S. (2006). Girişimcilik Keşif Süreci. İstanbul: Beta Basım Yayım.

Wakkee, I., Elfring, T., ve Monaghan, S. (2010). Creating Entrepreneurial Employees in Traditional Service Sectors The Role Of Coaching And SelfEfficacy. International Entrepreneurship Management, 6: 1-21.

Yalçıntaş, M. (2007). KOBI'ler ve Girişimcilik. Girişimcilik ve Kalkınma Dergisi, 2(2):145 148 .

Yıldırım, M. H., Demirel, Y., ve İçerli, L. (2011). İşletme Sahibi Yöneticilerin Girişimci Kişilik Özellikleri İle Girişimcilik Becerileri Arasındaki İlişkinin Tespiti: Aksaray Örneği. Organizasyon ve Yönetim Bilimleri Dergisi,3(2): 189-199. 